\title{
INDICATORS OF INTERNET NON-USE IN SAMPLE SURVEYS ON ICT USE: A QUALITATIVE ANALYSIS
}

\author{
Guilherme Alves da Silva and Leonelo Dell Anhol Almeida \\ Graduate Program in Technology and Society - Federal University of Technology - Paraná (UTFPR), \\ Brazil
}

\begin{abstract}
The digital divide/digital inclusion concepts have been of interest to policymakers, particularly since the 1990s. However, the social transformation promised with ICTs adoption and diffusion is more complicated than just providing access. Qualitative studies have emphasized the importance of analyzing skills, appropriation, and negotiation. Authors in the Human-Computer Interaction (HCI) studies and in the Science, Technology, and Society (STS) studies also argue that studying technology non-use is also valuable as it broadens the concept of user/non-user beyond a binary look, diving in to understand how people engage or disengage with technologies, besides bringing relevant outputs about why some people do not or cannot become an Internet user. In this paper, we take this approach to analyze national sample surveys carried out in the three most populated countries in Latin America and the Caribbean (Brazil, Mexico, and Colombia). Data from those surveys have directly been used to help formulate public policies in the three countries. We seek to identify indicators related to non-use present in the surveys, analyzing them in order to suggest the broadening of their scope. Besides specific questions about each survey, we find that all of them do not provide data, for example, on people who have stopped using the Internet (as a whole or part of it); do not consider people who access the network indirectly, by other people; and often bring, among motivations for non-use, sentences that do not reveal whether non-use is voluntary or involuntary. At the background of the discussion, we propose that further studies on technology non-use should be done in order to question technology determinism, the idea that everybody should and will become an Internet user.
\end{abstract}

\section{KEYWORDS}

Digital Inclusion, Digital Divide, Technology Non-Use, Internet Use, ICT Data 


\section{INTRODUCTION}

The "digital divide" has become a topic of interest to academic researchers and policymakers since the 1990s. It is usually addressed as a type of social inequality regarding why some people have and why some do not have access to Information and Communication Technologies (ICT), particularly the Internet (Castells, 2001). Concerns over this "divide" have gathered attention because access and use of ICTs are frequently seen as a path to socioeconomic development (ITU, 2005; Qiang, Rossoto \& Kimura, 2009); thus, increasing access to them has been a common goal in public policies over the 2000s and 2010s (Valente, 2012).

According to estimates from the International Telecommunication Union (ITU), an agency from the United Nations that collects data from countries about ICTs, at the end of 2019, $53.6 \%$ of the global population, or 4.1 billion people, were using the Internet (ITU, 2019a). The organization claims that over the last decade the number of Internet users grew consistently. However, ITU estimation shows a considerable variation between socioeconomic groups of countries: $86.6 \%$ of the population in developed countries, $47.0 \%$ in developing countries, and $19.1 \%$ in the least developed countries. That is a historical variation that has fostered the digital divide debate, particularly in the policymaking level within countries. A key example was the two phases of the first World Summit on the Information Society (WSIS), held in 2003 and 2005 by the United Nations. The primary outcomes from this global multilateral event were recommendations to governments to improve policies intended to overcome the digital divide as a leading strategy to socioeconomic development, particularly in developing countries (ITU, 2005).

Despite the relevance of discussions around access, such as studies on broadband infrastructure and affordability, scholars have pointed out that the physical access (to computers, smartphones and the broadband connection itself) is just part of the equation when it comes to an understanding of how social inequalities are shaped in the era of the Internet. Warschauer (2003), Silveira (2008), Becker (2009), Barbosa et al. (2016), DiMaggio $\&$ Hargittai (2001), among others, have emphasized that literacy, empowerment of people and communities, and development of skills become more meaningful as the access gap decreases — which has happened particularly over the 2010s. Even mistrust, often motivated by concerns on privacy when using Internet services and applications, should be considered when studying why people do not use the Internet (ISOC, 2017). In this sense, terms such as "digital exclusion," instead of the digital divide, have become more helpful to address the whole equation that deals with access and use, but also opportunities, knowledge, and skills, that should be considered in policies oriented to promote community development and opportunities (Maryland University, 2013; Silveira, 2008).

If usage has been one of the main topics on the digital divide/digital inclusion debate, in this paper we take an alternative approach: from use to "non-use." Recent studies in the Human-Computer Interaction (HCI) field, a research community in Computer Science, and also in Science, Technology and Society Studies (STS), an interdisciplinary field, suggest that studying non-use of technologies as a complex phenomenon, not only a "phase" of technology dissemination, could help us to understand why and how people engage or disengage with technologies (Baumer et al., 2015, 2014; Baumer \& Brubaker, 2017; Satchell \& Dourish, 2009; Wyatt, 2014, 2003; Wyatt, Thomas \& Terranova, 2002). Those studies also suggest that looking at non-use and non-users may help policymakers to become more aware of people's 
needs and interests instead of relying on technologies themselves as solutions to social inequalities. In the background, we place analysis from STS studies, such as from Feenberg (2017, 2009) and Dagnino (2010, 2013), that question views of technology determinism and neutrality that are often used to reinforce the idea that everyone will (and should) become an Internet user.

Our approach consists in analyzing indicators of non-use and non-users of the Internet in national sample surveys on ICT use in three Latin American and the Caribbean (LAC) countries: Brazil, Colombia, and Mexico. First, we present our literature review on digital inclusion and non-uses/non-users of technology, as well as categories of analysis on the latter as proposed by scholars in HCI and STS fields. Then, we turn to the surveys presenting their backgrounds and goals, placing them in the general policy scenario of data production intended to subsidize policies on the digital divide and digital inclusion. Finally, we analyze indicators of non-uses and non-users found in the surveys, aiming at understanding how they enable or not a broad analysis of how these phenomena are shaped in each country, as well as indicating possibilities of expanding their scope.

\section{LITERATURE REVIEW}

\subsection{From the "Digital Divide" to "Digital Inclusion"}

Since its very beginning, in the 1990s, the digital divide debate has gathered criticism because it was primarily focused on access to ICTs as if access itself was the solution of social inequalities, which was a deterministic approach.

Warschauer (2003) argues that once the use of ICTs, in general, has become relevant in the current globalized world, the study of use, more than just access, is a fundamental approach to address issues such as marginalization and social inclusion regarding technologies. The author criticizes the idea that technology itself can bring social inclusion regardless of the social/cultural context around it. DiMaggio and Hargittai (2001) proposed the Digital Inequality Theory as an alternative lens to the concept of the digital divide, suggesting that if the access divide tends to decrease, other sorts of inequality arise among Internet users, related to patterns, purposes and skills for using the network, a framework of analysis also considered by authors such as Reisdorf and Groselj (2017), Hargittai, Piper and Morris (2018) and Barbosa et al. (2016). Another approach, endorsed by Dijk (2005), also questions rhetorical around the concept of the digital divide, such as the idea that the "divide" is binary, ignoring that between having or not access there are fundamentally different experiences of use - and, we add, non-use. The author also emphasizes the importance of considering social markers such as race, ethnicity, gender, age, and income in the debate around differences in access and use of technology, an approach also examined by authors such as Deursen and Helsper (2015).

It is important to remember that most of those authors come from the context of the USA and Europe. In the LAC context, authors such as Silveira (2008) and Becker (2009) tend to advance toward a more socially-oriented approach considering the specific realities of the region. Silveira (2008) points out that the concept of "digital exclusion" has been used by Brazilian researchers as an alternative to the digital divide and connected to Social Sciences discussions around social inclusion and exclusion, that is, understanding factors related to 
IADIS International Journal on WWW/Internet

poverty, misery, and prejudice that prevent people from experiencing full citizenship. The digital exclusion/inclusion debate would then focus on understanding how the use of digital technologies, particularly the Internet, has to do with socio-economic development and empowerment for vulnerable communities. Becker (2009) takes a similar approach when she argues that we should look at the digital exclusion as a type of social exclusion established as a result of the creation and dissemination of the use of digital technology: a phenomenon not only attached to individual use of those technologies, but to a broader context of citizenship opportunities.

Though the digital divide concept is notably still the most used at the policymaking level, the digital inclusion perspective has gained space, for example, at the Internet Governance Forum (IGF), an annual multistakeholder event held under the United Nations support and delivered as a WSIS outcome. Recently both 2018 (IGF, 2018) and 2019 (IGF, 2019) editions set digital inclusion as one of their main themes, addressing discussions particularly concerned with Internet use and skills for use.

\subsection{Non-Use and Non-Users of the Internet: Beyond a Binary Look}

Discussions around the concept of "technology user" have been predominant in research in Human-Computer Interaction (HCI), an academic field from Computer Science (Baumer et al., 2015, 2014; Satchell and Dourish, 2009). Debates from this field are relevant once they are oriented to people and institutions concerned particularly with technology design and, by extension, with technology use. Indeed, Bødker (2006) explains that throughout HCI history, but particularly in what is called the "Third Wave of HCI," the study of "use" and the "user" has been expanded towards social and cultural contexts. Then, we understand that considering analyses from this field are relevant to our discussion mainly because we focus our analysis on the policymaking level.

Another academic field from which we find discussions around technology non-use is the Science, Technology, and Society Studies (STS Studies), an interdisciplinary area that emerged in the 1960s and 1970s, in parallel in the USA, Europe, and LAC. In that field, scholars have focused their analysis on questioning technology determinism and neutrality, arguing the need to understand the social dimensions in Science and Technology (S\&T), not only in their early development but also in their consequences - to the environment, the society and economics (Cutcliffe, 2003; Dagnino, 2013). Feenberg (2017, 2009), a Philosopher of Technology, also affiliate to the STS perspective when questioning the lack of democracy in the decisions around S\&T development: it happens under human intentions and interests; thus, human values are placed within S\&T shaping (Feenberg, 2017). Disclosing this dynamic is essential, so we may question, for example, the rhetoric around technology use that frequently sees it as compulsory, a final destiny from which people could never choose about.

Although the digital divide perspective still is the most used in the academic literature, alternative approaches, as we cited, have been considered. The study of non-use is particularly relevant considering the need for a non-binary look on the issue: once we understand better why people do not use the Internet, we may comprehend that the idea of "use" is complex does everybody use the Internet in the same way? Is it possible to level it out? Also, we may understand that people negotiate their relation with technologies differently according to their individual and social context - what "part" (that is, which services and applications) of the Internet an individual uses and what part they do not, and why? Those questions are not 
relevant only to regions, such as the USA and Europe, where access has become pervasive over the last decade (c.f. ITU, 2019a). Instead, we claim that even regions, such as LAC, that still lack infrastructure and affordability to access to the Internet, benefit from a broadening analysis of the non-use beyond a binary look once policymakers and technology developers may address the question considering other frameworks rather than affiliating only with a determinist perspective over technology use.

In the HCI field, Baumer et al. $(2014,2015)$ and Satchell \& Dourish (2009) claim that studying non-use allows understanding the full range of possible negotiations and engagements/disengagements that people have with technologies, particularly considering the idea of agency, i.e., being able to choose using or not using a specific technology, as well as how to use it. In Baumer et al. (2015), the authors claim the need to scrutinize the rhetoric of a "digital imperative," that is, the compulsory use of certain technologies. The key question is not whether the Internet or other technologies may or may not be beneficial to people, but how the rhetoric of compulsory use does not address the whole question of social implications of using the Internet towards a real improvement of people's lives. We also argue the need to consider that "users" also means, for most countries, "consumers": if policymakers seek to consider Internet usage beyond the consumption of devices and services, that usage should be understood critically and around a framework of technology dissemination in a bottom-up perspective - examples are community networks initiatives (Belli, Echániz, \& Iribarren, 2016) and the Free Software Movement (FSF, 2019).

In the STS Studies, Wyatt, Thomas \& Terranova (2002) argue that Internet access has been shaped as inherently good because there has been created an expectation of what people will do once they become a user. They would use it to develop professional skills and new business, to access educational content, and to have a voice in politics. Nevertheless, people could actually use the network to access pornography, bullying other people in social media, or have fun. Having a single model of what it is like being a user leaves little room to figure it out the Internet as a socio-technical system, open to many manifestations, including non-use (Wyatt, 2014, 2003).

Table 1 brings information of two groups of categories of non-use and non-users that we have chosen to consider in this paper, as proposed by Satchell \& Dourish (2009) and Wyatt, Thomas, \& Terranova (2002). Since there is an overlap between the groups of categories, and even categories of the same group that are variations of each other, we chose to present them all in interrelated sets, when possible. 
IADIS International Journal on WWW/Internet

Table 1. Types of non-use and non-users of technology and examples concerning the Internet

\begin{tabular}{|c|c|c|}
\hline Type & What it is & Examples \\
\hline $\begin{array}{l}\text { Lagging adoption } \\
\text { (Satchell \& } \\
\text { Dourish, 2009) }\end{array}$ & $\begin{array}{l}\text { An undetermined situation where people } \\
\text { are not users yet but will become soon. } \\
\text { The concept is used by the ones who } \\
\text { claim that technology adoption and } \\
\text { diffusion follow an expected pattern that } \\
\text { goes from early adopters to laggards. }\end{array}$ & $\begin{array}{l}\text { It is a deterministic view that does not consider } \\
\text { people's agency: non-use, in this case, is only a } \\
\text { "phase," and it would be a matter of time until } \\
\text { everybody becomes a user of successful technology. }\end{array}$ \\
\hline $\begin{array}{l}\text { Active resistance, } \\
\text { disenchantment or } \\
\text { disinterest (Satchell } \\
\text { \& Dourish, 2009) } \\
\text { Resisters (Wyatt, } \\
\text { Thomas \& } \\
\text { Terranova, 2002) }\end{array}$ & $\begin{array}{l}\text { A voluntary situation of people who } \\
\text { deliberately choose not to become users. } \\
\text { It questions the "lagging adoption" type } \\
\text { and proposes the idea that one can never } \\
\text { really become a user of a technology. It } \\
\text { often seems like a situation generated by } \\
\text { lack of education or event technophobia, } \\
\text { when it really encompasses many } \\
\text { different possibilities of disengagement } \\
\text { with technologies. The disenchantment } \\
\text { is a specific variation that refers to } \\
\text { people who choose not to become users } \\
\text { for a sense of nostalgia from an era } \\
\text { before the technology. }\end{array}$ & $\begin{array}{l}\text { It may happen due to concerns over privacy and } \\
\text { control of personal information or any other reason } \\
\text { that stimulates a positive effort to resist a technology. } \\
\text { In the case of the Internet, which is a techno-system, } \\
\text { it may also refer to people who do not want to use } \\
\text { specific services and applications due to political } \\
\text { reasons. The disenchantment situation is often } \\
\text { claimed by people who think that digital technologies } \\
\text { such as ICTs have a negative impact on their social or } \\
\text { community lives. Policymakers may benefit from the } \\
\text { opinions of those people to better understand social } \\
\text { transformations brought to light by ICTs use. }\end{array}$ \\
\hline $\begin{array}{l}\text { Rejectors (Wyatt, } \\
\text { Thomas \& } \\
\text { Terranova, 2002) }\end{array}$ & $\begin{array}{l}\text { A voluntary situation of people who had } \\
\text { been users and have chosen to stop } \\
\text { using the technology. }\end{array}$ & $\begin{array}{l}\text { People may stop using the Internet due to political } \\
\text { reasons, but also because they have found "offline" } \\
\text { ways of having the same social benefit they would } \\
\text { find "online." Alternatively, also because they prefer } \\
\text { to become "indirect" users (see Displacement). }\end{array}$ \\
\hline $\begin{array}{l}\text { Expelled (Wyatt, } \\
\text { Thomas \& } \\
\text { Terranova, 2002) }\end{array}$ & $\begin{array}{l}\text { An involuntary situation of people who } \\
\text { had been users and stopped using the } \\
\text { technology even if they wanted to } \\
\text { continue to use. }\end{array}$ & $\begin{array}{l}\text { One may stop using the Internet involuntarily because } \\
\text { they cannot pay for the connection anymore, have lost } \\
\text { access to their devices (computers, smartphones), or } \\
\text { even have lost institutional access (such as provided } \\
\text { by libraries or schools, or free wi-fi networks } \\
\text { provided by governments). Also, censorship and } \\
\text { online surveillance (both by other people, } \\
\text { governments, and companies) may lead a person to } \\
\text { leave the Internet even wanting to stay connected. }\end{array}$ \\
\hline $\begin{array}{l}\text { Disenfranchisement } \\
\text { (Satchell \& } \\
\text { Dourish, 2009) } \\
\text { Excluded (Wyatt, } \\
\text { Thomas \& } \\
\text { Terranova, 2002) }\end{array}$ & $\begin{array}{l}\text { An involuntary situation of people } \\
\text { prevented from usage by economic, } \\
\text { social, infrastructure and/or geographic } \\
\text { factors, among others. }\end{array}$ & $\begin{array}{l}\text { When merged with the "lagging adoption" type, it } \\
\text { often serves policymakers with rhetoric to propose } \\
\text { policies to overcome such involuntary factors that } \\
\text { prevent people from Internet usage. Particularly } \\
\text { relevant in developing countries, where economic } \\
\text { affordability and infrastructure are often fragile. It is } \\
\text { often claimed to explain why people do not use the } \\
\text { Internet yet. }\end{array}$ \\
\hline $\begin{array}{l}\text { Displacement } \\
\text { (Satchell \& Dourish, } \\
\text { 2009) }\end{array}$ & $\begin{array}{l}\text { An undetermined situation of people who } \\
\text { do not use a specific technology directly } \\
\text { but can be as affected by it as a daily user. }\end{array}$ & $\begin{array}{l}\text { Considering the pervasiveness of Internet services and } \\
\text { applications in many countries (particularly developed } \\
\text { ones), one could question if a person can really never use } \\
\text { the network even indirectly, for example, when they } \\
\text { provide personal data to have access to government } \\
\text { services. It also encompasses the case of people who asks } \\
\text { somebody else to access the Internet for them because } \\
\text { they do not know how to use it, does not have means for } \\
\text { it (connection or devices), or simply because they do not } \\
\text { want to. Indirect use craves attention because it questions } \\
\text { whether the "use" is only valid if individual and direct, or } \\
\text { if we need to broaden our scope of analysis. }\end{array}$ \\
\hline
\end{tabular}


Each of those categories opens a different possible approach to the non-use/non-user phenomena beyond a binary look and the idea that people do not use the Internet only due to lack of infrastructure, affordability, or skills. We argue that those categories can also be expanded, mixed, and changed according to each cultural and social reality. It makes sense to assume that people living in countries (particularly developed ones) where broadband infrastructure has reached the whole nation will be less likely to not become an Internet user due to lack of infrastructure. However, that does not mean that we cannot find people refusing to use the Internet based on a political decision even in countries (particularly developing ones) where lack of infrastructure is still a prevalent issue to prevent access. Assuming that only a group of motivations (voluntary or involuntary) plays a role in a social context is assuming a deterministic view on technology adoption and diffusion (c.f. Feenberg, 2017, 2009; Dagnino, 2010, 2013).

Moreover, we claim that studying non-use categories are relevant to policymakers not only as a tool to create policies so people will become users, but as a tool to better understand how people, in different contexts, engage or not with technologies — understanding, then, that public policies towards social inclusion are not always attached to technology dissemination, and also that technology usage should be taken around a framework of people empowerment.

\section{OUR APPROACH}

Considering our literature review, the research question brought to this paper is whether and how non-use and non-users of the Internet are considered in surveys on ICT usage at a national level in LAC. We focused our analysis on these surveys considering that they provide valuable data used by policymakers to validate and/or formulate policies around the digital divide/digital inclusion. National-based, these surveys intend to provide a trustful overview of ICT usage in each country. Therefore, we understand that analyzing them might have an impact on future policies.

Our sources selection followed a three-step method: countries, organizations, and surveys. First, we decided to target the three most populated countries in the LAC region; to select them, we turned to United Nations' World Population Prospects 2019 (UN, 2019), subsequently selecting Brazil, Mexico, and Colombia. Second, we turned to the ITU's Statistics Portal (ITU, 2019b), which lists the primary sources of national data used by the organization. Finally, to select the surveys, we accessed the websites of each of these organizations to find out their main national surveys.

The final report of each survey was obtained online. We reviewed each report separately, searching for, among all indicators present in the survey, the presence of indicators related to non-use of the Internet. We did not consider in this review indicators only on the number or percentage of people who do not use the Internet in each country since we aimed at understating reasons and motivations for the non-usage. The indicators, whether present, were then listed, and we analyzed both the question asked and the possible answers, having the help of the groups of categories for non-usage proposed by Satchell \& Dourish (2009) and Wyatt, Thomas \& Terranova (2002). Finally, we compared the three surveys, registering possible similarities or differences in how they consider or not the non-use and non-user of the Internet. 


\section{RESULTS}

This section is composed of three subsections. First, we present an overview of the organizations that carry out the surveys we analyzed, focusing on their background to disclose motivations behind the surveys. Second, we analyze the surveys, focusing on their methodologies. Third, we analyze the indicators of non-use and non-users of the Internet, raising qualitative questions about them based on our literature review.

\subsection{Organizations}

Table 2 summarizes basic information about the organizations listed in ITU's Statistics Portal as main sources of ICT data in the countries we selected to analyze in this paper. Following, we discuss the background and resonance in public policies of each of them.

Table 2. Organizations responsible for the surveys analyzed

\begin{tabular}{|l|l|l|l|l|}
\hline Country & \multicolumn{1}{|c|}{ Organization } & \multicolumn{1}{c|}{$\begin{array}{c}\text { Year of } \\
\text { foundation }\end{array}$} & \multicolumn{1}{c|}{ Type } & $\begin{array}{c}\text { Resonance in public } \\
\text { policies }\end{array}$ \\
\hline Brazil & $\begin{array}{l}\text { Núcleo de Informação e Coordenação } \\
\text { do Ponto BR (NIC.br) (Brazilian } \\
\text { Network Information Center), the } \\
\text { executive body of the Brazilian } \\
\text { Internet Steering Committee (CGI.br) }\end{array}$ & 2003 & $\begin{array}{l}\text { Private nonprofit civil } \\
\text { organization. CGI.br is a } \\
\text { multistakeholder } \\
\text { organization, created by } \\
\text { and run in partnership } \\
\text { with the Brazilian } \\
\text { Government }\end{array}$ & $\begin{array}{l}\text { National Broadband } \\
\text { Brazilian Digital } \\
\text { Transformation } \\
\text { Estrategy (2018) }\end{array}$ \\
\hline Mexico & $\begin{array}{l}\text { Instituto Nacional de Estadística y } \\
\text { Geografía (INEGI) (National Institute } \\
\text { of Statistics and Geography) }\end{array}$ & 1983 & $\begin{array}{l}\text { Autonomous body of } \\
\text { the Mexican } \\
\text { Government }\end{array}$ & $\begin{array}{l}\text { National Digital } \\
\text { Strategy (2014-2018) }\end{array}$ \\
\hline Colombia & $\begin{array}{l}\text { Departamento Administrativo } \\
\text { Nacional de Estadística (DANE) } \\
\text { (National Administrative Department } \\
\text { of Statistics) }\end{array}$ & 1951 & $\begin{array}{l}\text { Agency under the } \\
\text { Colombian Government }\end{array}$ & $\begin{array}{l}\text { ICT Plan 2018-2020 - } \\
\text { belongs to everyone }\end{array}$ \\
\hline
\end{tabular}

The Núcleo de Informação e Coordenação do Ponto BR (Brazilian Network Information Center - NIC.br) is a private nonprofit civil organization created in 2003 to implement decisions and projects designed by the Comitê Gestor da Internet no Brasil (Brazilian Internet Steering Committee - CGI.br) (NIC.br, 2020). CGI.br was created by the Brazilian Government in 1995, same year of the first regulation about Internet access by ordinary people (outside of universities), "with the purpose of coordinating and integrating all Internet service initiatives in Brazil, as well as promoting technical quality, innovation and the dissemination of the services available" (CGI.br, 2020). Currently, CGI.br is managed by 21 Board members, in a multistakeholder model: nine representatives from the Federal Government, four from the corporate sector, four from the third sector (civil society organizations), three from the scientific and technological community and one "Internet expert". Except for representatives from the Federal Government and the Internet expert (all indicated by the Government), other Board members are elected among their peers to a 3-year term (idem). Therefore, despite not administrated directly by the Government, the CGI.br, and, hence, the NIC.br, have a direct link with its interests and policies. When it comes to public resonance, 
we find a examples of public policies on digital divide/digital inclusion that have used data provided by NIC.br surveys: the Programa Nacional de Banda Larga (National Broadband Plan), a major group of policies carried out from 2010 to 2014 in order to increase broadband infrastructure and access in Brazil (CGPID, 2010), and the Estratégia Brasileira de Transformação Digital (Brazilian Digital Transformation Strategy), a report approved in 2018 that gathers guidelines and recommendations for public policies that correlates ICT use and economy, education, government, and civil rights (Government of Brazil, 2018).

The Instituto Nacional de Estadística y Geografia (National Institute of Statistics and Geography - INEGI) is an autonomous public body of Mexican Government, created in 1983 (INEGI, 2020). Despite being called "autonomous," INEGI is ruled by a Governing Board, with President and Vice-president appointed directly by the President of Mexico and approved by the Senate. The survey selected for this paper is one of the national surveys carried out regularly by INEGI, which provides nine other regular household-based surveys. It is considered by the Government of Mexico the main source of statistics about ICT use in households in the country (Government of Mexico, 2019), and it has influenced policies such as the Estrategia Digital Nacional (National Digital Strategy), approved in 2013 and employed from 2014 to 2018, which encompasses different socio-economic public policies on digital inclusion in the country (Government of Mexico, 2020).

The Departamento Administrativo Nacional de Estadística (National Administrative Department of Statistics - DANE) was created in 1951 by the Government of Colombia (DANE, 2020). It reports directly to the Presidency and is intended for planning, carrying out, and evaluating data for the National Statistical System (NSS). The head of DANE, titled Department Director, is appointed directly by the President of Colombia (DANE, 2020). As observed about the organizations in Brazil and Mexico, data provided by DANE has also been used in policies around the digital divide/digital inclusion in Colombia. The main example is the Plan TIC 2018-2022 - El futuro digital es de todos (ICT Plan 2018-2020 - The digital future belongs to everyone). Similar to the Brazilian Digital Transformation Strategy and the National Digital Strategy from Mexico, it is a guideline report for digital inclusion policies, digital economy, e-government, among other topics (Government of Colombia, 2018).

In summary, we find that all of the three organizations that carry out the surveys we selected to analyze in this paper are linked to national governments, although differently. Brazil is the only case of an organization that is not ruled by a staff directly appointed by a Government; however, even in this case, we find that the Government plays an important role in decision-making. Also, it is the only case of an organization created exclusively to operate around ICTs issues. Brazilian official statistics agency, the Instituto Brasileiro de Geografia e Estatística (Brazilian Institute of Geography and Statistics - IBGE), has done surveys in the past to collect data on ICTs use, but not regularly (latest report was in 2017).

Understanding the background of each organization is vital to disclose motivations behind the surveys. Since all of those surveys are oriented to assist policies aimed at increasing Internet access rates (NIC.br, 2019, p. 143; INEGI, 2018; DANE, 2019, p. 2), we instead assume that they will focus on usage. This understanding is important because when we claim the need to analyze non-use and non-users as a complex phenomenon - particularly if we do not take a deterministic view over technology diffusion - , we also assume that it is possible to both analyze uses and non-uses at the same time and with the same attention. They are not mutually excluding once they are part of a broader dynamic of how people negotiate their use of technologies, as cited by Baumer et al. $(2014,2015)$ and Satchell \& Dourish (2009). 
IADIS International Journal on WWW/Internet

\subsection{Surveys}

The Table 3 brings general information about each survey. Following, we discuss specific questions about methodologies on them:

Table 3. National surveys considered in this paper

\begin{tabular}{|c|c|c|c|c|}
\hline Country & Name of the survey & Type of survey & Methodology & Report \\
\hline Brazil & $\begin{array}{l}\text { "TIC Domicílios } 2018 \text { - Pesquisa Sobre o Uso } \\
\text { de Tecnologias de Informação e Comunicação } \\
\text { nos Domicílios Brasileiros" (ICT Households } \\
2018 \text { - Survey on the Use of Information and } \\
\text { Communication Technologies in Brazilian } \\
\text { Households) }\end{array}$ & $\begin{array}{l}\text { Stand-alone, national } \\
\text { sample survey with 9+ } \\
\text { years old people living in } \\
\text { all Brazilian federative } \\
\text { units, and urban and rural } \\
\text { areas }\end{array}$ & $\begin{array}{l}\text { Self-proposed, } \\
\text { based on } \\
\text { ITU's manual } \\
\text { (ITU, 2014) }\end{array}$ & $\begin{array}{l}2018- \\
2019 \\
\text { (NIC.br, } \\
\text { 2019) }\end{array}$ \\
\hline Mexico & $\begin{array}{l}\text { "ENDUTIH - Encuesta Nacional sobre } \\
\text { Disponibilidad y Uso de Tecnologías de la } \\
\text { Información en los Hogares" (National Survey } \\
\text { on Availability and Use of Information } \\
\text { Technologies in Households) }\end{array}$ & $\begin{array}{l}\text { National sample survey, } 6+ \\
\text { years old people living in } \\
\text { all Mexican regions, and } \\
\text { urban and rural areas }\end{array}$ & Self-proposed & $\begin{array}{l}2018 \\
\text { (INEGI, } \\
2018)\end{array}$ \\
\hline Colombia & $\begin{array}{l}\text { "Indicadores básicos de tenencia y uso de } \\
\text { Tecnologías de la Información y Comunicación } \\
\text { en hogares y personas de } 5 \text { y más años de edad } \\
\text { - Año 2018" (Basic indicators for possession } \\
\text { and use of Information and communication } \\
\text { technologies in households and by people aged } \\
5 \text { and more years old - Year 2018) }\end{array}$ & $\begin{array}{l}\text { National sample survey, } 5+ \\
\text { years old people living in } \\
\text { all Colombian regions, and } \\
\text { urban and rural areas }\end{array}$ & Self-proposed & $\begin{array}{l}2018 \\
\text { (DANE, } \\
2019)\end{array}$ \\
\hline
\end{tabular}

Both Mexican and Colombian surveys are carried out as part of a general household survey, while the Brazilian is a stand-alone type, which makes sense since NIC.br is the only organization that is focused entirely on ICTs. Despite differences, for example, in the minimum age considered valid for interviewees, what shows up as an important to our analysis is the methodology employed to determine who will and who will not be considered an "Internet user" in the surveys. While the Brazilian (NIC.br, 2019) considers "Internet user" a person who claimed that had used the Internet at least once, in the last 3 months before the survey, the Mexican (INEGI, 2018) considers a 12-month term. We did not find any similar information in the Colombian case (DANE, 2019). When comparing Mexico and Brazil, we find that people who were considered an "Internet user" in the first country could possibly not be placed in the same category in the latter. We understand that taking this variation into account is crucial to any analysis regarding the percentage of Internet users and non-users in each country or in the LAC region and that additional analysis of this data is needed in order to better understand, for example, ITU's statistics (ITU, 2019).

NIC.br explicitly cites ITU as one of its primary sources of methodology information to formulate survey indicators. ITU's Manual for Measuring ICT Access and Use by Households and Individuals - 2014 edition (ITU, 2014) is a handbook intended to orient national entities and organizations when collecting and producing data on ICTs. The main point of the Manual is to work in the standardization of data, making it possible to compare statistics from different countries later. What we see, however, is that when it comes to the main indicator the percentage of people in the world using or not the Internet - , often, the comparison is 
either not directly possible or even difficult. The concept of "Internet user" is presented in the manual as the indicator "HH7: Proportion of individuals using the Internet" (ITU, 2014). The document does not provide detailed information on why the 3-month period was chosen, only stating that this is the "suggested reference period" and that "country practices vary, but ideally, reference periods should be aligned in order to obtain comparable data" (ITU, 2014, p. 54). The ITU explains that, in the previous edition of the manual, in 2009, the reference period was 12 months - the same used by the Mexican survey (INEGI, 2018). Based on our literature review on technology non-use, we argue that this methodology, besides only quantitative, does not include, for example, people who only use the Internet intermediated by another person - as stated by the "displacement" type of non-use (Satchell \& Dourish, 2009).

While we understand that statistics standardization may set aside many qualitative aspects of a social scenario, we claim that more could be proposed in the case of the "Internet user" concept. For example: levels of skills for Internet use, qualitative aspects of Internet connection, and which groups of services and applications are used or not by people. Considering this ample room of possibilities weakens the concept of "Internet used" proposed by ITU as a trustful indicator of Internet diffusion in the world and what challenges countries have been facing in the matter.

\subsection{Indicators}

We proposed Table 4, which relates each type of non-use or non-user categories cited in our literature review and the categories presented in each national survey considered. We claim that it is not possible to correlate them individually since they all open many possibilities of analysis. Our exercise is intended only to point out that further understanding of these complex phenomena.

Table 4. Proposed relations between types of non-use/non-user - literature and national surveys

\begin{tabular}{|c|c|c|c|c|}
\hline Author & Types & NIC.br survey (Brazil) & INEGI survey (Mexico) & DANE survey (Colombia) \\
\hline \multirow{4}{*}{$\begin{array}{l}\text { Satchell \& } \\
\text { Dourish } \\
(2009)\end{array}$} & $\begin{array}{l}\text { Lagging } \\
\text { adoption }\end{array}$ & All reasons & All reasons & All reasons \\
\hline & $\begin{array}{l}\text { Active } \\
\text { resistance }\end{array}$ & $\begin{array}{l}\text { "Lack of interest", } \\
\text { "Concerns with security } \\
\text { and privacy", "To avoid } \\
\text { contact with dangerous } \\
\text { content" }\end{array}$ & $\begin{array}{l}\text { "Do not have interest or do } \\
\text { not need it" }\end{array}$ & $\begin{array}{l}\text { "Do not consider it needed", } \\
\text { "Other (security and } \\
\text { privacy reasons)" }\end{array}$ \\
\hline & $\begin{array}{l}\text { Disenchant- } \\
\text { ment }\end{array}$ & $\begin{array}{l}\text { "Lack of interest", } \\
\text { "Concerns with security } \\
\text { and privacy", "To avoid } \\
\text { contact with dangerous } \\
\text { content" }\end{array}$ & $\begin{array}{l}\text { "Do not have interest or do } \\
\text { not need it", "Not aware of } \\
\text { its utility" }\end{array}$ & $\begin{array}{l}\text { "Do not consider it needed", } \\
\text { "Other (security and } \\
\text { privacy reasons)" }\end{array}$ \\
\hline & $\begin{array}{l}\text { Disenfranchise- } \\
\text { ment }\end{array}$ & $\begin{array}{l}\text { "Lack of computer } \\
\text { skills", "No place to use } \\
\text { it", "Too expensive", } \\
\text { "Concerns with security } \\
\text { and privacy" }\end{array}$ & $\begin{array}{l}\text { "Lack of economic } \\
\text { resources", "Do not know } \\
\text { how to use it", "Not aware } \\
\text { of its utility", "Equipment } \\
\text { insufficient or without } \\
\text { capacity", "No provider or } \\
\text { infrastructure available in } \\
\text { the place" }\end{array}$ & $\begin{array}{l}\text { "Do not know how to use } \\
\text { it", "It is too expensive", } \\
\text { "Other (lack of service } \\
\text { coverage at the area)", } \\
\text { "Other (no permission for } \\
\text { use)", "Other (security and } \\
\text { privacy reasons)" }\end{array}$ \\
\hline
\end{tabular}


IADIS International Journal on WWW/Internet

\begin{tabular}{|c|c|c|c|c|}
\hline & Displacement & $\begin{array}{l}\text { "Lack of need", "Lack of } \\
\text { computer skills", "Too } \\
\text { expensive", "Concerns } \\
\text { with security and } \\
\text { privacy", "To avoid } \\
\text { contact with dangerous } \\
\text { content" }\end{array}$ & $\begin{array}{l}\text { "Lack of economic } \\
\text { resources", "Do not have } \\
\text { interest or do not need it", } \\
\text { "Do not know how to use } \\
\text { it", "Not aware of its } \\
\text { utility", "Equipment } \\
\text { insufficient or without } \\
\text { capacity", "No provider or } \\
\text { infrastructure available in } \\
\text { the place" }\end{array}$ & $\begin{array}{l}\text { "Do not know how to use } \\
\text { it", "Do not consider it } \\
\text { needed", "It is too } \\
\text { expensive", "Other (lack of } \\
\text { service coverage at the } \\
\text { area)", "Other (no } \\
\text { permission for use)", "Other } \\
\text { (security and privacy } \\
\text { reasons)" }\end{array}$ \\
\hline & Disinterest & $\begin{array}{l}\text { "Lack of need", "Lack of } \\
\text { interest", "Lack of } \\
\text { computer skills" }\end{array}$ & $\begin{array}{l}\text { "Do not have interest or do } \\
\text { not need it", "Do not know } \\
\text { how to use it", "Not aware } \\
\text { of its utility" }\end{array}$ & $\begin{array}{l}\text { "Do not know how to use } \\
\text { it", "Do not consider it } \\
\text { needed" }\end{array}$ \\
\hline \multirow[t]{5}{*}{$\begin{array}{l}\text { Wyatt, } \\
\text { Thomas \& } \\
\text { Terranova } \\
(2002)\end{array}$} & Resisters & $\begin{array}{l}\text { "Lack of need", "Lack of } \\
\text { interest", "Concerns with } \\
\text { security and privacy", } \\
\text { "To avoid contact with } \\
\text { dangerous content" }\end{array}$ & $\begin{array}{l}\text { "Do not have interest or do } \\
\text { not need it", "Not aware of } \\
\text { its utility" }\end{array}$ & $\begin{array}{l}\text { "Do not consider it needed", } \\
\text { "Other (security and } \\
\text { privacy reasons)" }\end{array}$ \\
\hline & Rejectors & $\begin{array}{l}\text { "Lack of need", "Lack of } \\
\text { interest", "Concerns with } \\
\text { security and privacy", } \\
\text { "To avoid contact with } \\
\text { dangerous content" } \\
\end{array}$ & $\begin{array}{l}\text { "Do not have interest or do } \\
\text { not need it", "Not aware of } \\
\text { its utility" }\end{array}$ & $\begin{array}{l}\text { "Do not consider it needed", } \\
\text { "Other (security and } \\
\text { privacy reasons)" }\end{array}$ \\
\hline & Excluded & $\begin{array}{l}\text { "Lack of need", "Lack of } \\
\text { computer skills", "No } \\
\text { place to use it", "Too } \\
\text { expensive", "Concerns } \\
\text { with security and } \\
\text { privacy", "To avoid } \\
\text { contact with dangerous } \\
\text { content" } \\
\end{array}$ & $\begin{array}{l}\text { "Lack of economic } \\
\text { resources", "Do not know } \\
\text { how to use it", "Not aware } \\
\text { of its utility", "Equipment } \\
\text { insufficient or without } \\
\text { capacity", "No provider or } \\
\text { infrastructure available in } \\
\text { the place" }\end{array}$ & $\begin{array}{l}\text { "Do not know how to use } \\
\text { it", "It is too expensive", } \\
\text { "Other (lack of service } \\
\text { coverage at the area)", } \\
\text { "Other (no permission for } \\
\text { use)", "Other (security and } \\
\text { privacy reasons)" }\end{array}$ \\
\hline & Expelled & $\begin{array}{l}\text { "Lack of computer } \\
\text { skills", "No place to use } \\
\text { it", "Too expensive", } \\
\text { "Concerns with security } \\
\text { and privacy", "To avoid } \\
\text { contact with dangerous } \\
\text { content" }\end{array}$ & $\begin{array}{l}\text { "Lack of economic } \\
\text { resources", "Do not know } \\
\text { how to use it", "Not aware } \\
\text { of its utility", "Equipment } \\
\text { insufficient or without } \\
\text { capacity", "No provider or } \\
\text { infrastructure available in } \\
\text { the place" }\end{array}$ & $\begin{array}{l}\text { "Do not know how to use } \\
\text { it", "It is too expensive", } \\
\text { "Other (lack of service } \\
\text { coverage at the area)", } \\
\text { "Other (no permission for } \\
\text { use)", "Other (security and } \\
\text { privacy reasons)" }\end{array}$ \\
\hline & $\begin{array}{l}\text { Not possible to } \\
\text { determine }\end{array}$ & $\begin{array}{l}\text { "Other reason", "Does } \\
\text { not know", "Did not } \\
\text { answer" }\end{array}$ & "Other", "Not specified" & "Other" \\
\hline
\end{tabular}

In the case of the TIC Domicílios 2018, the Brazilian survey (NIC.br, 2019, there are two indicators related to non-users: "C15 - Individuals who have never accessed the internet, by reasons for never having used it" (NIC.br, 2019, pp. 305-307) and "C15A - Individuals who have never accessed the internet, by main reason for never having used it" (NIC.br, 2019, pp. 308-310). In the first question, eight possible answers are presented: "Lack of need", "Lack of interest", "Lack of computer skills", "No place to use it", "Too expensive", "Concerns with security and privacy", "To avoid contact with dangerous content", and "Other reason". In this first question, the person surveyed could indicate as many reasons as they wanted. In the second question, only the main reason was asked, with two more possible answers: "Does not know" and "Did not answer". The main reasons pointed out were "Lack of interest" (27\%), "Lack of computer skills" (27\%), and "Too expensive" (16\%). We understand 
as positive the possibility of choosing more than one reason at the same time, while also having a single indicator to determine the main reasons. However, we find it important to consider in the analysis people who claim to use the Internet in periods shorter from the minimum to be considered a user according to the survey methodology ( 3 months) - here are $6 \%$ of the population analyzed, according to the indicator "C2 - Individuals who accessed the Internet by last access" (NIC.br, 2019, p. 286). There is an indication that NIC.br has already addressed the need to expand the concept of "Internet user" beyond the proposed by the ITU. The indicator "C2A - Internet users - expanded indicator", created in the 2016 edition of the survey, has been developed by the research team of NIC.br as an extension of the basic indicator "C2 - Individuals, last access to the Internet". It considers as Internet user those who, in other indicators, have answered that use mobile phones and, according to the applications used, are using the Internet: this indicator, the NIC.br (2009) explains, was created because the organization has observed that some interviewees, despite using Internet applications in their mobile phones (such as instant messaging apps), are not aware that they are, in fact, using the Internet.

In the case of ENDUTIH, the Mexican survey (INEGI, 2018), the indicator "Households with a computer and that do not have an Internet connection, according to main reasons" brings eight different reasons for non-use of the Internet, but attached only to households with a computer, which excludes those who neither have a computer and any other device nor an Internet connection (INEGI, 2018). The possible reasons were: "Lack of economic resources", "Do not have interest or do not need it", "Do not know how to use it", "Not aware of its utility", "Equipment insufficient or without capacity", "No provider or infrastructure available in the place", "Other", and "Not specified". We suggest that broadening this indicator to investigate why households, regardless of having a computer or not, do not have an Internet connection, may be useful to understand precisely why part of Mexican households owns neither the equipment nor the connection, and why. We find it essential to disassociate personal computers as the main or primary device to access the Internet: as ITU (2019a) has pointed out, mobile phones and mobile connection (such as $3 \mathrm{G}, 4 \mathrm{G}$, and even $\mathrm{Wi}-\mathrm{Fi}$ ) have been playing an important role in the diffusion and adoption of the network over the last decade. Finally, despite a household-based survey, ENDUTIH also provides data based on individuals' responses; however, there is no indicator of non-use of the Internet oriented to them. The indicator "Users of smartphones with access to the internet, who access it or not through a mobile connection" is the only one related to non-use, but it does not bring reasons for each situation. Following the previous case, we suggest adding specific questions to people who declare themselves non-users of the Internet, regardless of the type of equipment or device they do or do not have.

In the case of the Colombian survey, the only indicator related to non-use is titled "Distribution of people who do not use the Internet, according to the main reason for non-use" (DANE, 2019, p. 24). Four possible answers were presented: "Do not know how to use it" ( $44.8 \%$ of the total population who claimed that do not use the Internet), "Do not consider it needed" (24.2\%), "It is too expensive" (18.1\%), and "Other" (12,9\%). According to a footnote, the last possible answer groups "lack of service coverage at the area, no permission for use, security and privacy reasons, and others" (idem). Compared to the surveys of the other two countries, the Colombian offers a limited number of reasons for non-use (4 against 8 in both Brazilian and Mexican surveys). It is not clear if the reasons grouped in the "Other" option were presented in that way due to lower prevalence compared to the other options or any other reason. Notwithstanding, following Table 1 explanation on the types of user titled 
IADIS International Journal on WWW/Internet

"expelled"/"excluded" (Wyatt, Thomas \& Terranova, 2002) or "disenfranchisement" (Satchell $\&$ Dourish, 2009), we argue that the reason "no permission for use" is vague, because it could embed many different involuntary reasons.

The first suggestion to all of the surveys is asking if interviewees have ever stopped using the Internet, a specific service or application, or a specific group of services and applications (such as social media, e-commerce, or instant messaging). The type of motivations also matters: if concerns privacy, cybersecurity, or political issues, it might be a valuable piece of information for policymakers when addressing regulation and policies on privacy, data protection, or even online human rights (regarding freedom of speech or social minorities). Further qualitative analysis could determine whether those motivations were voluntary or involuntary. If it concerns people who have found an alternative, "offline" way for "online" services and applications, it may represent that it is a voluntary situation. However, a qualitative analysis might realize whether the person considers the possibility of coming back online or not. If it concerns costs, infrastructure, or availability of the service, it might help policymakers when proposing policies on affordability and broadband expansion. In all those cases, we would encompass the types of non-use and non-users titled "rejectors" (Wyatt, Thomas \& Terranova, 2002), if the situation is voluntary, or "expelled" (idem), if involuntary.

Investigating if interviewees ask for somebody else to access services and applications for them is also valuable. Again, the type of motivation matters: if the situation happens due to lack of know-how, devices or connection, it is probably an involuntary situation. That piece of information is helpful for policymakers to address digital inclusion programs focused on education or affordability. If it happens voluntarily, due to an "active resistance" or "displacement" (Satchell \& Dourish, 2009), it is also valuable information because it weakens the rhetoric of compulsory use present in the "lagging adoption" perspective (Satchell \& Dourish, 2009).

We understand that some reasons present in the surveys are vague since it is not possible to determine whether they are voluntary or involuntary. Mexican ENDUTIH, for example, has as one of its reasons "Equipment insufficient or without capacity", but it is not clear what does that really mean: "equipment without capacity" would be a computer with no Internet connection input? Or does the person have access to a fixed broadband connection, but only have a mobile phone/smartphone, which uses mobile connections? Even when it comes to concerns with privacy (reasons "Concerns with security and privacy" in the Brazilian TIC Domicílios, and "Other (no security and privacy)" in the Colombian survey), it is not clear if the situation is voluntary or involuntary. One could refuse to use the Internet because they do not agree with business models employed by big online players such as Google and Facebook considering their privacy policies; however, another person could have privacy concerns due to lack of education about how to use the Internet safely. Both cases are encompassed in the reasons cited but are relevantly distinct to policymakers as inputs to new policies.

\section{CONCLUSION}

In this paper, we chose an alternative path to the discussion on the use and appropriation of the Internet to bring a recent approach to non-use and non-users of technology as phenomena. Focusing on non-use and non-users, as proposed in the literature review, enables us to identify that policymaking process often supports rhetoric of compulsory use of technology as a direct 
measure of socioeconomic development, though discussions on digital inclusion claim that access and use without further qualitative action do not mean social inclusion. Supporting social inclusion policies that stimulate access and use of the Internet should also mean discuss whether this inclusion is merely a commercial issue or a broader social issue that connects inequality of technology dissemination to social marginalization.

By examining national sample surveys in the three most populated countries in Latin American and the Caribbean region, we see that even though they all have indicators related to non-use of the Internet, further indicators could be proposed in order to understand non-use as a phenomenon related to possible negotiations and engagements/disengagements that people have with the Internet. Understanding that those surveys provide data to researchers and policymakers, a broader consideration of the non-use of the Internet can have a positive impact on new research studies and new public policies in those countries.

That is particularly relevant considering that we are talking about a technology that enables a growing number of different services that people can engage with or not. Reasons concerning non-use as a deliberate choice, economic or cultural prevention, or even a temporary condition are equally relevant as the ones related to lack of infrastructure and affordability. Moreover, although the discussion on non-use of technology as a phenomenon has become relevant in the context of the USA and Europe, we understand that it is useful also to examine the context of developing countries. That is said considering that public policies intended to increase access could foster, in fact, a socially-oriented approach to technology dissemination, avoiding an acritical proposal that sees the technology itself as a solution rhetoric widely scrutinized by scholars who critique technology determinism.

\section{ACKNOWLEDGEMENT}

This paper was financed in part by the Coordenação de Aperfeiçoamento de Pessoal de Nível Superior - Brasil (CAPES).

\section{REFERENCES}

Barbosa, A., Bittencourt, A., Senne, F., Oyadomari, W., 2016. Acesso às tecnologias de informação e comunicação no Brasil: uma perspectiva da demanda por banda larga, in: Knight, P.T., Feferman, F., Foditsch, N. (Eds.). Banda larga no Brasil: passado, presente e futuro. Figurati, São Paulo, pp. 149-168.

Baumer, E. P. S., Brubaker, J. R., 2017. Post-userism, in: Proceedings of the 2017 CHI Conference on Human Factors in Computing Systems - CHI '17. Presented at the the 2017 CHI Conference, ACM Press, Denver, Colorado, pp. 6291-6303. Available at: <https://doi.org/10.1145/3025453.3025740> (Accessed: 29 December 2019).

Baumer, E.P.S., Ames, M.G., Brubaker, J.R., Burrell, J., Dourish, P., 2014. Refusing, limiting, departing: why we should study technology non-use, in: Proceedings of the Extended Abstracts of the 32nd Annual ACM Conference on Human Factors in Computing Systems - CHI EA '14. Presented at the the extended abstracts of the 32nd annual ACM conference, ACM Press, Toronto, Ontario, Canada, pp. 65-68. Available at: <https://doi.org/10.1145/2559206.2559224> (Accessed: 29 December 2019). 
IADIS International Journal on WWW/Internet

Baumer, E.P.S., Ames, M.G., Brubaker, J.R., Burrell, J., Dourish, P., 2015. On the importance and implications of studying technology non-use. interactions 22, pp. 52-56. Available at: <https://doi.org/10.1145/2723667> (Accessed: 29 December 2019).

Becker, M.L., 2009. Inclusão digital e cidadania: as possibilidades e as ilusões da solução tecnológica. EDUEPG, Ponta Grossa, PR.

Belli, L., Echániz, N., Iribarren, G., 2016. Fostering Connectivity and Empowering People via Community Networks: the case of AlterMundi, in: Belli, L. (Ed.), Community Connectivity: Building the Internet from Scratch: Annual Report of the UN IGF Dynamic Coalition on Community Connectivity. FGV Direito Rio, Rio de Janeiro, pp. 31-54.

Bødker, S., 2006. When second wave HCI meets third wave challenges, in: Proceedings of the 4th Nordic Conference on Human-Computer Interaction Changing Roles - NordiCHI '06. Presented at the the 4th Nordic conference, ACM Press, Oslo, Norway, pp. 1-8. Available at: <https://doi.org/10.1145/1182475.1182476> (Accessed: 29 December 2019).

Brazilian Internet Steering Committee (CGI.br), 2020. About. Available at: 〈https://cgi.br/about/> (Accessed: 17 April 2020).

Brazilian Network Information Center (Centro de Informação e Comunicação do Ponto BR - NIC.br), 2020. Who we are. Available at: < https://nic.br/who-we-are/> (Accessed: 17 April 2020).

(ed.), 2019. TIC domicílios 2018: Pesquisa sobre o uso das tecnologias de informação e comunicação nos domicílios brasileiros. Comitê Gestor da Internet no Brasil (CGI.br), São Paulo. Available at: <https://cetic.br/media/docs/publicacoes/2/12225320191028tic_dom_2018_livro_eletronico.pdf> (Accessed: 29 December 2019).

Castells, M., 2001. The Internet galaxy: reflections on the Internet, business, and society. Oxford University Press, Oxford, New York.

Comitê Gestor do Programa de Inclusão Digital (CGPID). (2010). Brasil conectado: Programa Nacional de Banda Larga. $66 . \quad$ p. Available at: <http://bibliotecadigital.seplan.planejamento.gov.br/bitstream/handle/iditem/225/documento-basedo-programa-nacional-de-banda-larga.pdf?sequence=1> (Accessed: 17 April 2020).

Cutcliffe, S. H., 2003. Ideas, máquinas y valores: los estudios de Ciencia, Tecnología y Sociedad. Ciencia, Tecnología y Sociedad, 14. Anthropos, Barcelona, 2003.

Dagnino, R., 2010. A Tecnologia Social e seus desafios. in: Dagnino, R. (Org.), Tecnologia social: Ferramenta para construir outra sociedade. 2. ed., Komedi, pp. 53-70.

2013. O Pensamento Latino-Americano em Ciência, Tecnologia e Sociedade (PLACTS) e a obra de Andrew Feenberg. in: Neder, R. T. (Org.), A teoria crítica de Andrew Feenberg: Racionalização democrática, poder e tecnologia. 2 ed., Observatório do Movimento pela Tecnologia Social na América Latina/ CDS/ UnB/ Capes, pp. 25-48). Available at: <https://www.sfu.ca/ andrewf/coletanea.pdf> (Accessed: 17 April 2020).

Deursen, A. van, Helsper, E.J., 2015. The Third-Level Digital Divide: Who Benefits Most from Being Online?, in: Robinson, L., Cotten, S.R., Schulz, J., Hale, T.M., Williams, A. (Eds.), Studies in Media and Communications. Emerald Group Publishing Limited, pp. 29-52. Available at: <https://doi.org/10.1108/S2050-206020150000010002> (Accessed: 29 December 2019).

Dijk, J.A.G.M. van, 2005. The Deepening Divide: Inequality in the Information Society. SAGE Publications, Inc.

DiMaggio, P., Hargittai, E., 2001. From the "Digital Divide" to "Digital Inequality": Studying Internet Use as Penetration Increases. Working Papers, Princeton University, Woodrow Wilson School of Public and International Affairs, Center for Arts and Cultural Policy Studies.

Feenberg, A., 2009. Critical Theory of Technology: An Overview. in: J. Buschman \& G. J. Leckie (Orgs.), Information technology in librarianship new critical approaches. Libraries Unlimited, pp. 31-44. 
2017. Critical theory of technology and STS. Thesis Eleven, 138(1), pp. 3-12. Availabel at: <https://doi.org/10.1177/0725513616689388> (Accessed: 17 April 2020).

Free Software Foundation (FSF), 2019. What is Free Software. Available at: <https://www.fsf.org/about/what-is-free-software> (Accessed: 29 December 2019).

Government of Brazil, 2018. Ministry for Science, Technology, Innovation and Communication. Estratégia Brasileira de Transformação Digital. Informatics Policy Secretariat, Brasília. Available at: <http://www.mctic.gov.br/mctic/export/sites/institucional/estrategiadigital.pdf> (Accessed: 17 April 2020).

Government of Colombia, 2018. Plan TIC 2018-2022 - El futuro digital es de todos. Available at: <https://www.mintic.gov.co/portal/604/articles-101922_Plan_TIC.pdf> (Accessed: 17 April 2020).

Government of Mexico, 2019. Secretariat for Communications and Transport. En México hay 74.3 millones de usuarios de internet y 18.3 millones de hogares con conexión a este servicio: ENDUTIH 2018. Available at: < https://www.gob.mx/sct/prensa/en-mexico-hay-74-3-millones-de-usuarios-deinternet-y-18-3-millones-de-hogares-con-conexion-a-este-servicio-endutih-2018-196013?idiom=es > (Accessed: 17 April 2020). 2020).

2020. México Digital. Available at: < https://www.gob.mx/mexicodigital> (Accessed: 17 April

Hargittai, E., Piper, A.M., Morris, M.R., 2018. From internet access to internet skills: digital inequality among older adults. Univ Access Inf Soc. Available at: 〈https://doi.org/10.1007/s10209-018-0617-5> (Accessed: 29 December 2019).

International Telecommunication Union (ITU), 2005. World Summit on the Information Society Outcome Documents - Geneva 2003 - Tunis 2005. ITU, Geneva. Available at: <https://www.itu.int/net/wsis/outcome/booklet.pdf> (Accessed: 29 December 2019).

2014. Manual for Measuring ICT Access and Use by Households and Individuals - 2014 edition. ITU, Geneva. Available at: <https://www.itu.int/dms_pub/itu-d/opb/ind/D-IND-ITCMEAS2009-PDF-E.pdf> (Accessed: 17 April 2020).

2019a. Measuring digital development, Facts and figures 2019. ITU, Geneva. Available at: <https://www.itu.int/en/ITU-D/Statistics/Documents/facts/FactsFigures2019.pdf> (Accessed: 29 December 2019).

2019b. Percentage of Individuals using the Internet - 2000-2018, updated in December 2019. Available at: $\quad<$ https://www.itu.int/en/ITUD/Statistics/Documents/statistics/2019/Individuals_Internet_2000-2018_Dec2019.xls> (Accessed: 29 December 2019).

Internet Governance Forum (IGF), 2018. Chair's Summary \& IGF Messages. Available at: $<$ http://www.intgovforum.org/ (Accessed: 29 December 2019).

, 2019. IGF 2019 Workshop Selection Results. Available at: <https://www.intgovforum.org/ multilingual/content/igf-2019-workshop-selection-results> (Accessed: 29 December 2019).

Internet Society, 2017. Internet Society Global Internet Report: Paths to Our Digital Future. Available at: $\quad<$ https://future.internetsociety.org/2017/wp-content/uploads/sites/3/2017/09/2017-InternetSociety-Global-Internet-Report-Paths-to-Our-Digital-Future.pdf $>$ (Accessed: 29 December 2019).

Maryland University, 2013. What is Digital Inclusion? Digital Inclusion Survey. Available at: $<$ https://digitalinclusion.umd.edu/content/what-digital-inclusion> (Accessed: 29 December 2019).

National Administrative Department of Statistics (Departamento Administrativo Nacional de EstadísticaDANE), 2019. Boletín Técnico - Indicadores básicos de tenencia y uso de Tecnologías de la Información y Comunicación - TIC en hogares y personas de 5 y más años de edad - 2018. Available at: <https://www.dane.gov.co/files/investigaciones/boletines/tic/bol_tic_hogares_departamental_ 2018.pdf> (Accessed: 29 December 2019). 
IADIS International Journal on WWW/Internet

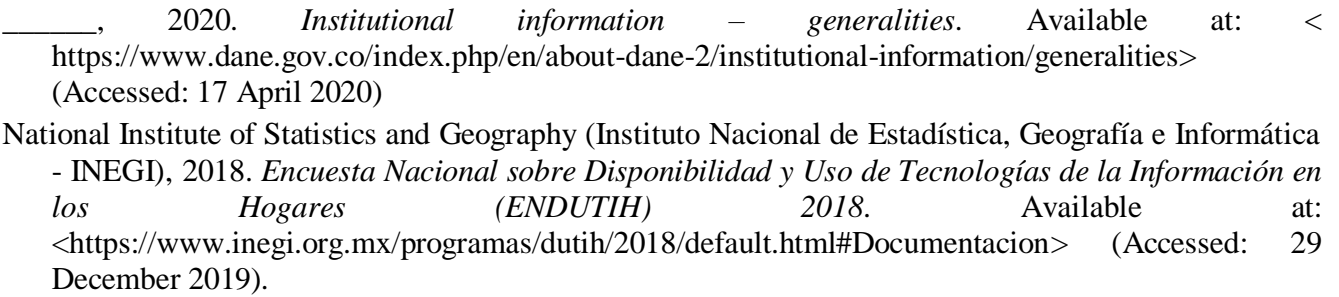
, 2020. Instituto. Available at: <http://en.www.inegi.org.mx/inegi/contenido/instituto.html> (Accessed: 17 April 2020).

Qiang, C. Z.-W., Rossoto, C. M., Kimura, K., 2009. Economic impacts of broadband. in: World Bank. 2009 information and communications for development: extending reach and increasing impact. The World Bank, Washington DC. v. 3. pp. 35-50. Available at: <http://documents.worldbank.org/curated/pt/645821468337815208/pdf/487910PUB0EPI1 101Officia 10Use0Only1.pdf> (Accessed: 17 April 2020).

Reisdorf, B.C., Groselj, D., 2017. Internet (non-)use types and motivational access: Implications for digital inequalities research. New Media \& Society 19, pp. 1157-1176. Available at: <https://doi.org/10.1177/1461444815621539> (Accessed: 29 December 2019).

Satchell, C., Dourish, P., 2009. Beyond the user: use and non-use in HCI, in: Proceedings of the 21st Annual Conference of the Australian Computer-Human Interaction Special Interest Group on Design: Open 24/7 - OZCHI '09. Presented at the the 21st Annual Conference of the Australian Computer-Human Interaction Special Interest Group, ACM Press, Melbourne, Australia, p. 9. Available at: <https://doi.org/10.1145/1738826.1738829> (Accessed: 29 December 2019).

Silveira, S.A. da, 2008. A noção de exclusão digital diante das exigências de uma cibercidadania, in: Hetkowski, T.M. (Ed.), Políticas Públicas \& Inclusão Digital. EDUFBA, Salvador, pp. 43-66.

United Nations, 2019. World Population Prospects 2019. Department of Economic and Social Affairs, Population Dynamics. Available at: <https://population.un.org/wpp/Download/Standard/Population/> (Accessed: 29 December 2019).

Valente, J. C. L., 2012. Planos nacionais de banda larga e o papel dos Estados na universalização do serviço. in: Silva, S. P., Biondi, A. (Org.). Caminhos para a universalização da internet banda larga: experiências internacionais e desafios brasileiros. 1 ed. Intervozes, São Paulo, pp. 79-114. Available at: 〈http://www.intervozes.org.br/arquivos/interliv008cpunibl.pdf> (Accessed: 17 April 2020).

Warschauer, M., 2003. Technology and social inclusion: rethinking the digital divide. MIT Press, Cambridge, Mass.

Wyatt, S., 2003. Non-Users Also Matter: The Construction of Users and Non-Users of the Internet, in: Oudshoorn, N., Pinch, T. (Eds.), How Users Matter: The Co-Construction of Users and Technologies, Inside Technology. MIT Press, Cambridge, Mass, pp. 67-80.

. Bringing users and non-users into being across methods and disciplines. in: Refusing, Limiting, Departing - Workshop Considering Why We Should Study Technology Non-Use. Toronto, Canada, $2014 . \quad$ Available at: <http://nonuse.jedbrubaker.com/wpcontent/uploads/2014/03/Wyatt_Toronto_April_2014.pdf> (Accessed: 17 April 2020).

Wyatt, S., Thomas, G., Terranova, T., 2002. They Came, They Surfed, They Went Back to the Beach: Conceptualizing Use and Non-Use of the Internet, in: Woolgar, S. (Ed.), Virtual Society? Technology, Cyberbole, Reality. Oxford University Press, Oxford; New York, pp. 23-40. 